\title{
Review
}

\section{The Hidden Role of Hydrogen Sulfide Metabolism in Cancer}

\author{
Rong-Hsuan Wang ${ }^{1,+}$, Yu-Hsin Chu ${ }^{1,2,+}$ and Kai-Ti Lin 1,3,*D \\ 1 Institute of Biotechnology, College of Life Science, National Tsing Hua University, Hsinchu 300, Taiwan; \\ rong_hsuan_wang@gapp.nthu.edu.tw (R.-H.W.); rsp9840827@gmail.com (Y.-H.C.) \\ 2 Department of Life Science, College of Life Science, National Tsing Hua University, Hsinchu 300, Taiwan \\ 3 Department of Medical Science, College of Life Science, National Tsing Hua University, Hsinchu 300, Taiwan \\ * Correspondence: ktlin@life.nthu.edu.tw \\ + Both authors contributed equally.
}

Citation: Wang, R.-H.; Chu, Y.-H.;

Lin, K.-T. The Hidden Role of

Hydrogen Sulfide Metabolism in

Cancer. Int. J. Mol. Sci. 2021, 22, 6562.

https://doi.org/10.3390/ijms22126562

Academic Editors: Maria

E. Mycielska, Sebastian Haferkamp and Eric Parkinson

Received: 30 April 2021

Accepted: 14 June 2021

Published: 18 June 2021

Publisher's Note: MDPI stays neutral with regard to jurisdictional claims in published maps and institutional affiliations.

\begin{abstract}
Hydrogen Sulfide $\left(\mathrm{H}_{2} \mathrm{~S}\right)$, an endogenously produced gasotransmitter, is involved in various important physiological and disease conditions, including vasodilation, stimulation of cellular bioenergetics, anti-inflammation, and pro-angiogenesis. In cancer, aberrant up-regulation of $\mathrm{H}_{2} \mathrm{~S}$ producing enzymes is frequently observed in different cancer types. The recognition that tumorderived $\mathrm{H}_{2} \mathrm{~S}$ plays various roles during cancer development reveals opportunities to target $\mathrm{H}_{2} \mathrm{~S}$ mediated signaling pathways in cancer therapy. In this review, we will focus on the mechanism of $\mathrm{H}_{2} \mathrm{~S}$-mediated protein persulfidation and the detailed information about the dysregulation of $\mathrm{H}_{2} \mathrm{~S}$-producing enzymes and metabolism in different cancer types. We will also provide an update on mechanisms of $\mathrm{H}_{2} \mathrm{~S}$-mediated cancer progression and summarize current options to modulate $\mathrm{H}_{2} \mathrm{~S}$ production for cancer therapy.
\end{abstract}

Keywords: hydrogen sulfide; gasotransmitter; persulfidation; cystathionine $\beta$-synthase; cystathionine $\gamma$-lyase; 3-mercaptopyruvate sulfurtransferase; cancer metabolism

\section{Introduction}

Hydrogen sulfide $\left(\mathrm{H}_{2} \mathrm{~S}\right)$, a colorless, flammable, water-soluble gas, is recognized as the third gasotransmitter in 2002 [1]. Similar to the other two gasotransmitters, nitric oxide (NO) or carbon monoxide (CO), $\mathrm{H}_{2} \mathrm{~S}$ acts as a critical mediator in multiple physiological processes, including regulation of blood vessel vasodilation [2-4], cardiac response to ischemia/reperfusion injury [5], and inflammation [6]. In mammalian cells, $\mathrm{H}_{2} \mathrm{~S}$ is actively synthesized endogenously by three enzymes: cystathionine $\beta$-synthase (CBS), cystathionine $\gamma$-lyase (CTH), and 3-mercaptopyruvate sulfurtransferase (3-MST) [1,7]. Accumulated evidence indicates that dysregulation of these $\mathrm{H}_{2} \mathrm{~S}$ producing enzymes was observed in multiple cancer types (See Section 4), suggesting $\mathrm{H}_{2} \mathrm{~S}$ may play an important role during cancer development. Therefore, in this review, we will summarize the current understanding of $\mathrm{H}_{2} \mathrm{~S}$ production, regulation, and biological functions during cancer development. We will particularly focus on how $\mathrm{H}_{2} \mathrm{~S}$-mediated protein persulfidation accomplishes cancer formation in different aspects of cancer hallmarks.

\section{Hydrogen Sulfide}

$\mathrm{H}_{2} \mathrm{~S}$ is a colorless gas that smells like rotten eggs at low concentrations. Bernardino Ramazzini, the father of occupational health, wrote De Morbis Artificum Diatriba [8] (Diseases of Workers) in 1700. He described the effects of sewer gas exposure on the sewer workers, which causes irritation and inflammation to their eyes. In the early 19th century, people found out the major cause was $\mathrm{H}_{2} \mathrm{~S}$ appearance in sewers that caused these harmful effects [9]. From then on, numerous toxicological effects of $\mathrm{H}_{2} \mathrm{~S}$ on animals including humans have been reported [10,11]. Interestingly, although $\mathrm{H}_{2} \mathrm{~S}$ was well-known as an environmental toxin, it can also be produced endogenously in bacteria [12], plants [13,14], 
and animals $[15,16]$. However, endogenously produced $\mathrm{H}_{2} \mathrm{~S}$ was considered as a metabolic waste for a long time until $\mathrm{K}$ Abe and $\mathrm{H}$ Kimura suggested that the endogenous $\mathrm{H}_{2} \mathrm{~S}$ functions as a neuromodulator in the brain in 1996 [17]. A few years later, Rui Wang proposed that $\mathrm{H}_{2} \mathrm{~S}$ serves as the third gasotransmitter [1], while the first is $\mathrm{NO}$ and the second is $\mathrm{CO}$. Gasotransmitters are endogenously produced small gaseous molecules and play different roles in multiple physiological conditions $[18,19]$. As the third gasotransmitter, $\mathrm{H}_{2} \mathrm{~S}$ modulates a wide range of physiological processes, including smooth muscle relaxation [20,21], vasorelaxation [4], regulation of myocardial ischemia-reperfusion injury [22-24], neuron protection [25-27], inflammation [6,28,29], and angiogenesis [30,31].

\section{Hydrogen Sulfide Mediated Protein Persulfidation}

$\mathrm{H}_{2} \mathrm{~S}$ regulates diverse cellular signaling pathways through persulfidation (Ssulfhydration) [3,32-45]. This novel and reversible posttranslational modification covalently adds a thiol group (-SH) to active cysteine residue (PSH/PS-) in its target protein, which forms protein persulfidation (PSSH/PSS ${ }^{-}$) (Figure 1A) [46]. The direct reaction between cysteine residue on the protein and hydrogen sulfide is unfeasible because of the thermodynamic constrains resulted from the release of hydrogen gas. Zhang et al. addressed several potential pathways for persulfidation under physiological conditions (Figure 1B,C) [47], including the reaction of S-Sulfenylated (PSOH) [48] or S-Nitrosated (PSNO) [49] proteins to form S-sulfhydrated modification through $\mathrm{H}_{2} \mathrm{~S}$ [47]. In addition, protein disulfides can be reduced by $\mathrm{H}_{2} \mathrm{~S}$ to form $\mathrm{S}$-sulfhydrated proteins [50]. However, incubation of disulfide-containing protein, such as BSA [47] or immunoglobulin [51], with $\mathrm{H}_{2} \mathrm{~S}$ did not lead to any detectable protein persulfidation. $\mathrm{H}_{2} \mathrm{~S}$ can also be oxidized by metal centers such as heme iron and converted to HS• radical [52], which subsequently reacts with protein thiol and $\mathrm{O}_{2}$ to give protein persulfides in the end [47]. Furthermore, Greiner et al. confirmed the presence of polysulfides in NaHS solution and suggested that perhaps polysulfides are the actual persulfidating mediators than $\mathrm{H}_{2} \mathrm{~S}$ (Figure 1C) [53]. Moreover, glutathione persulfide (GSSH/(GSS-) and cysteine persulfide (CysSSH/ CysSS-), both are highly presented in mammalian cells and tissues, also thought of as possible persulfidating agents (Figure 1C) [54].

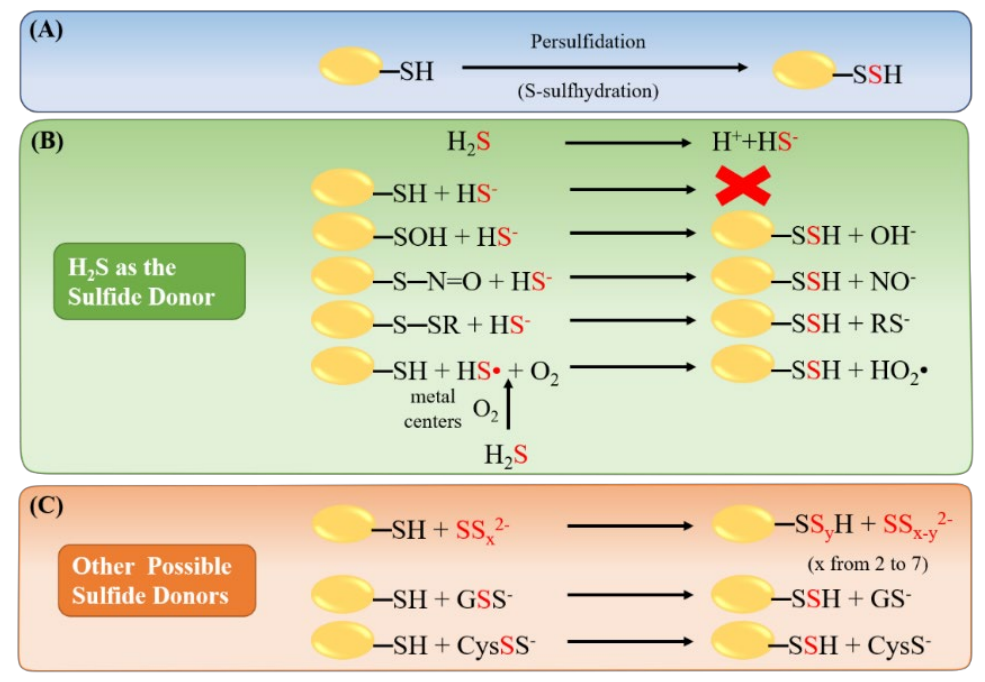

Figure 1. Possible reaction mechanisms for protein persulfidation. (A) Illustration of protein persulfidation, also called protein S-sulfhydration. (B) Proposed possible persulfidating reaction by $\mathrm{H}_{2} \mathrm{~S}$ as the sulfide donor. In solution, $\mathrm{H}_{2} \mathrm{~S}$ will dissociate into $\mathrm{HS}^{-}$and $\mathrm{H}^{+}$. A direct reaction between protein thiol and $\mathrm{HS}^{-}$is impossible. In contrast, persulfidation can result from a sulfide anion on an oxidized protein thiol, including S-OH, S-N=O, and S-SR. HS• radical can be generated by $\mathrm{H}_{2} \mathrm{~S}$ through oxidation by metal centers. HS• will then react $\mathrm{O}_{2}$ to generate protein persulfidation and $\mathrm{HO}_{2} \bullet$. (C) Other sulfide donors, such as polysulfides, glutathione persulfide (GSS ${ }^{-}$), and cysteine persulfide $\left(\mathrm{CysSS}^{-}\right)$, may also act as persulfidating agents to stimulate protein persulfidation. 


\section{Regulation of Hydrogen Sulfide Production in Cancer}

$\mathrm{H}_{2} \mathrm{~S}$ has been admitted as a regulator of tumor progression and metastasis in recent years [55]. Endogenous $\mathrm{H}_{2} \mathrm{~S}$ is catalyzed by three different $\mathrm{H}_{2} \mathrm{~S}$-producing enzymes, $\mathrm{CBS}$, $\mathrm{CTH}$, and 3-MST (Figure 2) [1,7]. Dysregulation of $\mathrm{H}_{2} \mathrm{~S}$-producing enzymes has been discovered in many cancer types (Summarized in Table 1). By regulating the expression of $\mathrm{H}_{2} \mathrm{~S}$-producing enzymes, the amount of tumor-derived $\mathrm{H}_{2} \mathrm{~S}$ is changed, thereby altering the tumor microenvironment and affecting tumor growth and metastasis [56]. Therefore, in this section, we will summarize recent findings to unveil the possible regulatory mechanisms to modulate $\mathrm{H}_{2} \mathrm{~S}$ production during cancer development.

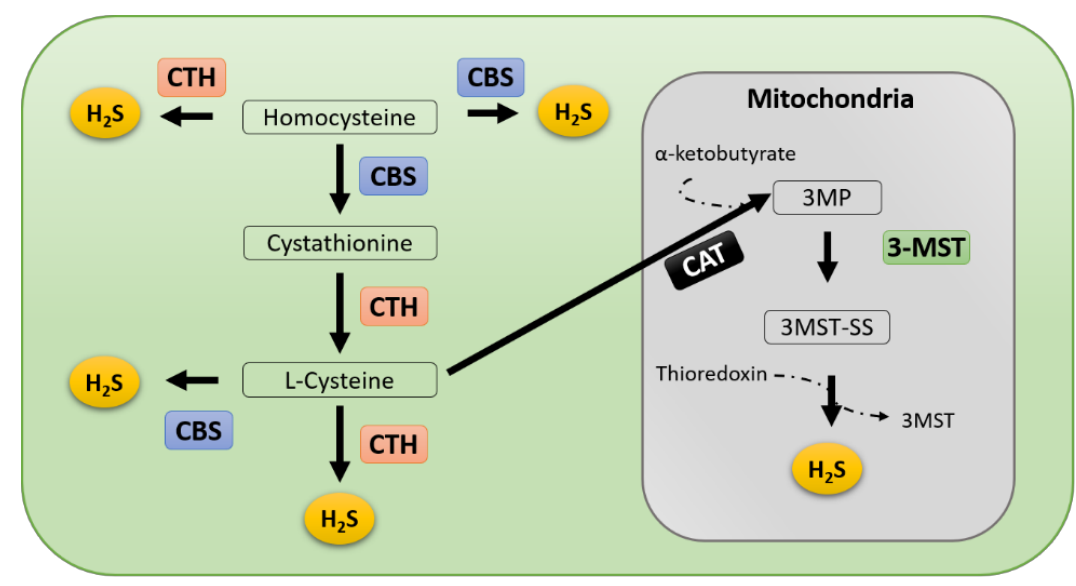

Figure 2. Simplified illustration of endogenous $\mathrm{H}_{2} \mathrm{~S}$ production pathways. Three principal enzymes responsible for $\mathrm{H}_{2} \mathrm{~S}$ production are CBS, $\mathrm{CTH}$, and 3-MST. Homocysteine is the major substrate for $\mathrm{H}_{2} \mathrm{~S}$ production. CTH and CBS generate $\mathrm{H}_{2} \mathrm{~S}$ majorly in the cytosol, while 3-MST generate $\mathrm{H}_{2} \mathrm{~S}$ in mitochondria. CBS, cystathionine $\beta$-synthase; CTH, cystathionine $\gamma$-lyase, 3-MST, 3-mercaptopyruvate sulfurtransferase; CAT, cysteine aminotransferase.

Table 1. Overview of upregulation and downregulation of three $\mathrm{H}_{2} \mathrm{~S}$ producing enzymes in different cancer types.

\begin{tabular}{|c|c|c|}
\hline $\mathrm{H}_{2} \mathrm{~S}$-Producing Enzymes & Dysregulation & Cancer Types \\
\hline \multirow{7}{*}{ CBS } & \multirow{5}{*}{ Upregulation } & colon cancer [57] \\
\hline & & ovarian cancer [58] \\
\hline & & breast cancer [59] \\
\hline & & thyroid cancer [60] \\
\hline & & gallbladder adenocarcinoma [61] \\
\hline & \multirow{2}{*}{ Downregulation } & hepatocellular carcinoma [62] \\
\hline & & gastrointestinal cancer [63] \\
\hline \multirow{7}{*}{ СТH } & \multirow{6}{*}{ Upregulation } & breast cancer [64] \\
\hline & & prostate cancer [65] \\
\hline & & gastric cancer [66] \\
\hline & & bladder cancer [67] \\
\hline & & hepatoma [68] \\
\hline & & colon cancer [69] \\
\hline & Downregulation & clear cell renal cell carcinoma [70] \\
\hline \multirow{3}{*}{ 3-MST } & \multirow{2}{*}{ Upregulation } & glioma tumor [71] \\
\hline & & colon cancer [72] \\
\hline & Downregulation & Unknown \\
\hline
\end{tabular}




\section{1. $C B S$}

CBS, which catalyzes $\mathrm{H}_{2} \mathrm{~S}$ by driving beta-replacement, has been observed to be selectively upregulated in colon cancer, ovarian cancer, breast cancer, thyroid cancer, and gallbladder adenocarcinoma tissues $[57,60,61,73]$. CBS is a constitutively expressed enzyme and its activity can be regulated post-translationally [74]. The first reported post-translational modification of CBS is the small ubiquitin-like modifier (SUMO) modification [75]. SUMOylation facilitates CBS to translocate into the nucleus and further losses its catalytic activity [76]. Other than SUMOylation, CBS can be S-glutathionylated and then phosphorylated under oxidative stress, resulting in the increased activity of CBS and subsequent $\mathrm{H}_{2} \mathrm{~S}$ production $[77,78]$. The catalytic activity of $\mathrm{CBS}$ can also be inhibited by the other two gasotransmitters, $\mathrm{CO}$ and $\mathrm{NO}$, through binding to the ferrous heme of CBS [79]. Tu et al. observed that the DNA methylation on the CpG island of CBS promoter facilitates cell proliferation in colon cancer [80]. The activity of CBS could be allosterically elevated by S-adenosylmethionine (SAM), a universal methyl donor, which stabilizes CBS [81,82], to promote cell proliferation in colon cancer cells [83]. Additionally, CBS can also be controlled via its redox sensitivity through ${ }^{272} \mathrm{CXXC}^{275}$ motif [84]. Under reductive-stress conditions, the redox-active disulfide bond $\left(\mathrm{Cys}^{272}-\mathrm{Cys}^{275}\right.$ ) harbored by the CXXC motif induces the activity of $\mathrm{CBS}$ and further amplifies $\mathrm{H}_{2} \mathrm{~S}$ production [84]. In contrast to the numerous studies in which CBS overexpression stimulates tumor growth in different cancer types, decreased CBS levels were also observed in glioma tumor cells, gastrointestinal cancer cells, and hepatocellular carcinoma $[62,63,85]$. The underlying mechanism remains unclarified, and reduced expression of CBS in glioma tumor cells may cause upregulation of 3-MST to generate $\mathrm{H}_{2} \mathrm{~S}$ production alternatively [86].

\section{2. $\mathrm{CTH}$}

$\mathrm{CTH}$, another $\mathrm{H}_{2} \mathrm{~S}$-producing enzyme, is demonstrated as being up-regulated in several different cancer types, including prostate cancer, gastric cancer, and melanoma cells $[45,66,87]$. CTH is highly expressed in the liver, kidney, and brain [74]. Unlike CBS, $\mathrm{CTH}$ is an inducible protein stimulated by oxidative stress, ER stress, Golgi stress, inflammation, and starvation [88]. Expression of CTH is primarily controlled at the transcriptional level in response to cellular stress [74]. Nuclear factor (erythroid-derived 2)-like 2 (Nrf2) is a transcription factor responsible for antioxidant stress [89]. Under oxidative stress, Nrf2 induces CTH expression through binding to its antioxidant response element (ARE) at $5^{\prime}$-untranslated region (UTR) [90], resulting in the increased level of $\mathrm{H}_{2} \mathrm{~S}$ production, and in turn, $\mathrm{H}_{2} \mathrm{~S}$ stimulates $\mathrm{Nrf} 2$ expression as positive feedback [90]. Overexpression of another transcription factor, specificity protein (SP) 1 , also modulates $\mathrm{H}_{2} \mathrm{~S}$ generation through binding and activating to the core promoter of $\mathrm{CTH}$ [91]. Tumor necrosis factor $\alpha$ (TNF $\alpha$ ) promotes $\mathrm{H}_{2} \mathrm{~S}$ production through this $\mathrm{SP} 1$ mediated CTH expression pathway [33]. In prostate cancer, overexpression of $\mathrm{CTH}$ increased $\mathrm{H}_{2} \mathrm{~S}$ production leads to the activation of nuclear factor- $\mathrm{KB}$ (NF- $\mathrm{kB}$ )-mediated interleukin $1 \beta$ (IL-1 $\beta$ ) signaling, resulting in the enhanced cell invasion, angiogenesis, lymphangiogenesis, tumor growth, and metastasis in prostate cancer [45]. In addition, induction of CTH expression by signal transducer and activator of transcription 3 (STAT3) signaling facilitates cell proliferation and migration in breast cancer, whereas induction of CTH expression by Wnt / $\beta$-catenin pathway stimulates cell proliferation in colon cancer $[64,69]$. CTH is also involved in the hepatoma cell proliferation via phosphorylation of extracellular signal-regulated protein kinase 1/2 (ERK1/2) through $\mathrm{H}_{2} \mathrm{~S}$ [68].

\subsection{3-MST}

3-MST is the only pyridoxal $5^{\prime}$-phosphate (PLP)-independent $\mathrm{H}_{2} \mathrm{~S}$-producing enzyme [74]. Unlike CBS and CTH, the catalytic activity of 3-MST is primarily regulated through its redox-sensitive characteristics [74], in which 3-MST is activated via oxidation at $\mathrm{Cys}^{247}$, the catalytically active site of 3-MST [92,93]. Although up-regulation of 3-MST in different cancer tissues has been confirmed, the underlying mechanism of 3-MST mediated 
$\mathrm{H}_{2} \mathrm{~S}$ signaling is rarely discussed before [87,94]. Recently, several 3-MST inhibitors have been developed and the function of 3-MST in cancer can now be studied through inhibition of 3-MST activity [94,95]. More investigations will be needed to understand the underlying mechanism of 3-MST to evaluate the therapeutic potential of 3-MST specific inhibitors.

\subsection{Hypoxia-Induced $\mathrm{H}_{2} \mathrm{~S}$ Production}

In cancer, hypoxia is a common feature of the microenvironment in solid tumors [96]. It is important to note that hypoxia profoundly evaluates the level of $\mathrm{H}_{2} \mathrm{~S}$ because it inhibits the catabolism of $\mathrm{H}_{2} \mathrm{~S}$ [97] and induces the expression of CTH [98]. Although the number of mitochondria decreases in cancer cells, mitochondria in cancer cells exhibit maximal sulfide-detoxifying capacity and a high level of sulfide:quinone oxidoreductase (SQR), which helps to transfer the $\mathrm{H}_{2} \mathrm{~S}$-derived electrons to the coenzyme $\mathrm{Q}$ (CoQ) [99]. The expression of $\mathrm{H}_{2} \mathrm{~S}$-producing enzymes and their translocation into mitochondria is enhanced under hypoxia, and subsequently increases the level of $\mathrm{H}_{2} \mathrm{~S}[56,98]$. In addition, $\mathrm{H}_{2} \mathrm{~S}$ can stimulate ischemia-induced angiogenesis by enhancing the expression of hypoxiainducible factor 1-alpha (HIF-1 $\alpha$ ) [73]. Zhou et al. revealed that $\mathrm{H}_{2} \mathrm{~S}$ downregulated the expression of miR-640 and enhanced the expression of HIF- $1 \alpha$ through the VEGFR2/mTOR pathway [100]. Wang et al. suggested that $\mathrm{H}_{2} \mathrm{~S}$ might mediate HIF- $1 \alpha$ via the PI3K/AKT pathway and promote the expression of vascular endothelial growth factor (VEGF) in non-small cell lung cancer [101]. In conclusion, cancer cells under hypoxia may produce $\mathrm{H}_{2} \mathrm{~S}$ through induction of $\mathrm{CTH}$ to facilitate angiogenesis [102] and tumor growth.

\section{The Role of Hydrogen Sulfide in Cancer}

Dysregulation of $\mathrm{H}_{2} \mathrm{~S}$-producing enzymes was observed in multiple cancer types and hypoxia conditions as mentioned in the previous section, resulting in the increased level of endogenous $\mathrm{H}_{2} \mathrm{~S}$, thus contributing to cancer development in different aspects. In this section, we will focus on how $\mathrm{H}_{2} \mathrm{~S}$ contributes to cancer progression through targeting different cancer hallmarks, including anti-apoptosis, DNA repair, tumor growth, cancer metabolism, metastasis, and angiogenesis (Summarized in Figure 3).

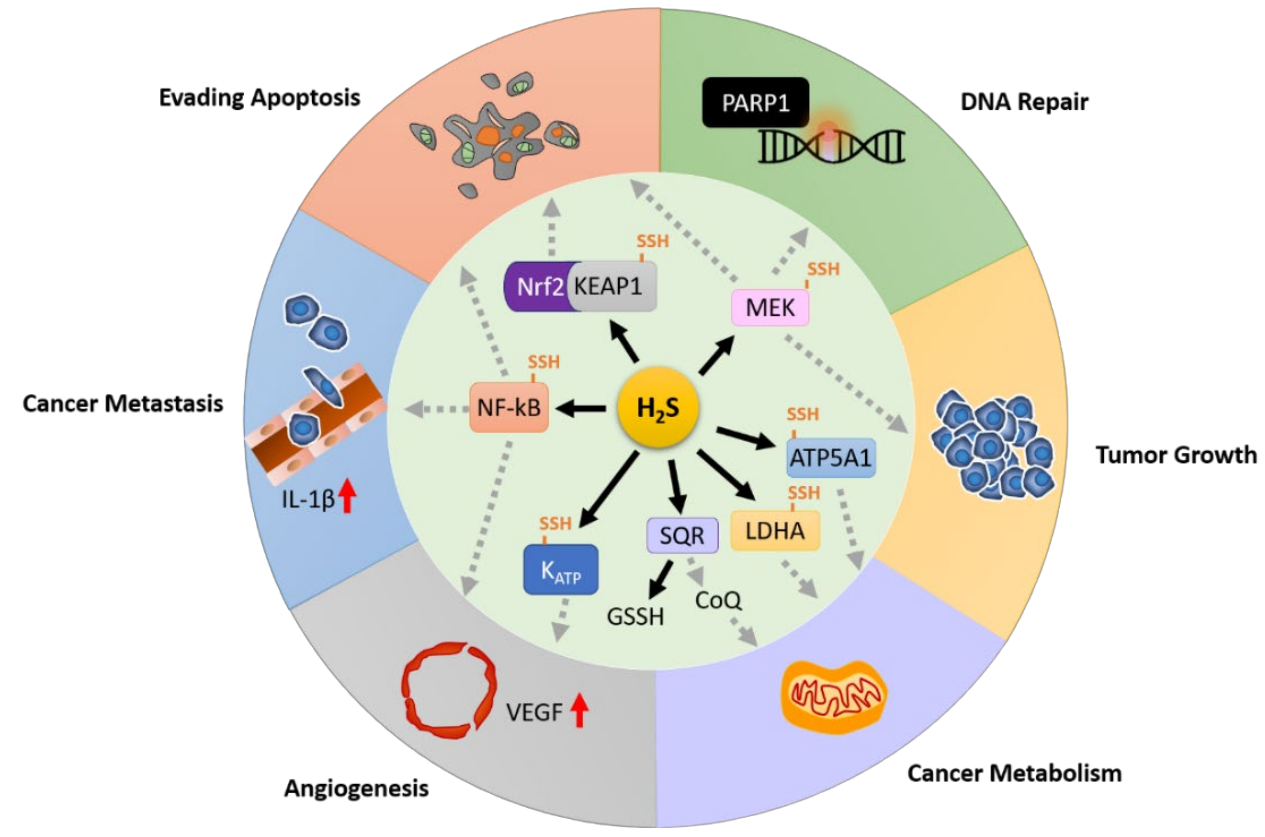

Figure 3. The potential role of $\mathrm{H}_{2} \mathrm{~S}$ during cancer development. Illustration of the six cancer hallmarks mediated by $\mathrm{H}_{2} \mathrm{~S}$ modulated protein persulfidation or using $\mathrm{H}_{2} \mathrm{~S}$ as a metabolic substrate for electron transfer. 


\subsection{Hydrogen Sulfide in Anti-Apoptosis}

Apoptosis is a naturally occurred and programmed cell death process in physiological and pathological conditions [103]. Evading apoptosis, one of the hallmarks during cancer progression, allows cancer cells to survive under various stresses [104]. The anti-apoptosis role of $\mathrm{H}_{2} \mathrm{~S}$ has been recognized in different disease models, such as cardiovascular diseases [105], ischemia-reperfusion injury [106], and multiple cancer types [107-110]. One of the potential mechanisms of $\mathrm{H}_{2} \mathrm{~S}$-mediated suppression of apoptosis is scavenging reactive oxygen species (ROS) and reactive nitrogen species (RNS) by exerting the activities of classic antioxidants, like GSH and Trx, leading to profound antioxidant protection in cells [74]. The other potential mechanism is the activation of anti-apoptotic pathways through $\mathrm{H}_{2} \mathrm{~S}$-linked persulfidation on NF- $\mathrm{KB}$ [33], Kelch-like ECH-associated protein 1 (Keap1) [34], and Mitogen-activated protein kinase kinase1 (MEK1) [36].

Activation of NF- $\mathrm{kB}$ signaling stimulates multiple anti-apoptotic genes, including $\mathrm{X}$-linked inhibitor of apoptosis protein (XIAP), cellular Inhibitors of Apoptosis Proteins (cIAPs), and the B-cell lymphoma 2 gene (Bcl-2) [111]. Activation of NF- $\mathrm{KB}$ requires translocation of NF- $\mathrm{kB}$ to the nucleus [111]. Persulfidation of NF- $\mathrm{kB}$ p65 subunit at $\mathrm{Cys}^{38}$ promotes its nuclear translocation [45] and promoter binding to those anti-apoptotic genes [33], resulting in the suppression of cellular apoptosis pathways [24,33].

Keap1, another protein mediated by persulfidation, is an adaptor of the Keap1-Cul3RBX1 E3 ligase complex, which targets Nrf2 to proteasomal degradation through polyubiquitination [112]. Nrf2 is a transcription factor that controls genes containing antioxidant response elements (AREs) in their regulatory regions to escape from apoptosis [112]. Through $\mathrm{H}_{2} \mathrm{~S}$-mediated persulfidation at $\mathrm{Cys}^{151}$, Keap1 can undergo a conformational change which leads to the dissociation of Nrf2 from the Keap1-Cul3-RBX1 E3 ligase complex, and subsequently, the free Nrf2 translocates into the nucleus to exert its role on apoptosis escape $[24,34,38,42,90]$.

MEK1, also known as MAP2K1, is one of the classical MAP kinase families that control a wide range of different cellular activities [113]. Activation of ERK1/2 by MEK1 generally inhibits apoptosis through modulating expressions of apoptotic-related proteins, including Bad, Bim-EL, Caspase 9, MCL-1, and TNFR [113]. Persulfidation of MEK1 at Cys ${ }^{341}$ leads to the phosphorylation of ERK1/2 and translocation of ERK1/2 into the nucleus to stimulate ERK1/2 mediated downstream signals in human endothelial cells and fibroblasts [36]. However, currently there is no direct evidence proving whether expressions of those apoptotic related genes are enhanced upon persulfidation of MEK1, more studies will be needed to clarify the role of persulfidation of MEK1 in anti-apoptosis.

\subsection{Hydrogen Sulfide in DNA Repair}

Protein poly [ADP-ribose] polymerase 1 (PARP1) is a well-known sensor of DNA single or double strand breaks, and thus it can initiate DNA damage repair pathways [114]. PARP1 inhibitor has been developed to create synthetic lethality of DNA repair systems in BRCA mutated cancers [115]. The idea is by blocking DNA repair pathways through PARP1 inhibitor in BRCA mutated cancers, the DNA damage responses will initiate signaling pathways to promote cell-cycle checkpoint activation, thus apoptosis will be triggered to eliminate cancer cells efficiently [115]. A study on MEK1 persulfidation indicates that persulfidation on MEK1 at $\mathrm{Cys}^{341}$ leads to MEK1 phosphorylation and translocation into the nucleus to stimulate PARP-1 activation and DNA damage repair, protecting cells from senescence [36]. Therefore, the activation of PARP1 through $\mathrm{H}_{2} \mathrm{~S}$ mediated signaling may help to promote damaged cancer cell survival during cancer development.

In addition to stimulating DNA repair pathway in cell nucleus, $\mathrm{H}_{2} \mathrm{~S}$ also helps mitochondrial DNA (mtDNA) repair through persulfidation on mt-specific DNA repair enzymes EXOG at $\mathrm{Cys}^{76}$ [116]. The stimulation of this mtDNA repair pathway by $\mathrm{H}_{2} \mathrm{~S}$ thus results in the apoptotic resistance to the cancer standard chemotherapy. 


\subsection{Hydrogen Sulfide in Tumor Growth}

Elevated $\mathrm{H}_{2} \mathrm{~S}$-producing enzymes have been observed in multiple cancer types $[45,57,64,94]$, and depletion of CBS or CTH activities results in the suppression of tumor growth in colon cancer [57], lung cancer [116], prostate cancer [45], and breast cancer [117]. Activation of MEK1, which belongs to the classical MAPK kinase pathways, is synonymous with cell proliferation and tumor growth [113]. Therefore, it is highly possible that ERK1/2 activities, which can be stimulated by $\mathrm{H}_{2} \mathrm{~S}$-mediated persulfidation on MEK1 [36], are the key drivers to promote tumor growth in CBS or CTH overexpressing tumors.

\subsection{Hydrogen Sulfide in Cancer Metabolism}

Exogenous $\mathrm{H}_{2} \mathrm{~S}$ has a long history as an environmental toxin through inhibition of mitochondrial Complex IV, leading to the suppression of mitochondrial electron transport and inhibits aerobic ATP generation [118]. In contrast, endogenously produced $\mathrm{H}_{2} \mathrm{~S}$ acts differently in mitochondria and cell metabolism. In mitochondria, $\mathrm{H}_{2} \mathrm{~S}$ acts as a metabolic substrate to stimulates the mitochondrial electron transport chain [119]. Mitochondria are the powerhouse of cells to generate ATP via oxidative phosphorylation (OXPHOS). $\mathrm{H}_{2} \mathrm{~S}$ oxidation by $\mathrm{SQR}$, the mitochondrial respiratory Complex II, leads electron transfer to coenzyme $Q(C o Q)$, facilitating the aerobic respiratory ATP synthesis [119]. In addition to serve as a metabolic substrate in the mitochondrial electron transport chain, $\mathrm{H}_{2} \mathrm{~S}$ also increases the catalytic activity of mitochondria ATP synthase through persulfidation at $\mathrm{Cys}^{244}$ and $\mathrm{Cys}^{294}$ on the $\alpha$ subunit of ATP synthase (ATP5A1) [120], which may result in the higher ATP production in mitochondria through aerobic respiration. In cancer, currently it is still unclear whether this $\mathrm{H}_{2} \mathrm{~S}$-mediated mitochondria ATP production contributes to cancer progression, and we may guess tumor cells may generate ATP through this pathway only when $\mathrm{O}_{2}$ supply is sufficient.

On the other hand, tumor cells require the acquisition of necessary nutrients from the poor environment and utilize these nutrients to maintain viability and build new biomass [121]. To support their high growth rates on proliferation, cancer cells preferentially convert glucose to lactate by aerobic glycolysis even in the presence of sufficient $\mathrm{O}_{2}$ [121]. This phenomenon is so called Warburg effect [122], in which cancer cells adapt glycolysis to use the intermediates of the glycolysis to synthesize lipids, fatty acids, and nucleotides required for uncontrolled cell proliferation. To do that, cancer cells utilize lactate dehydrogenase A (LDHA) to elevate the rate of glycolysis [123]. The enzyme activity of LDHA thus is considered as a therapeutic target for the suppression of tumor growth and distant metastasis in different cancer types [123]. $\mathrm{H}_{2} \mathrm{~S}$-mediated persulfidation of LDHA at $\mathrm{Cys}^{163}$ enhanced its enzymatic activity, leading to the increased production of lactate in HCT116 colon cancer cells [124]. Consistent with these observations, depletion of $\mathrm{H}_{2} \mathrm{~S}$ production by CBS knockdown resulted in the reduced oxygen consumption and ATP production in both colon cancer [57] and ovarian cancer cells [58], indicating the importance of $\mathrm{H}_{2} \mathrm{~S}$ in the modulation of cancer metabolism to support tumor cell uncontrolled growth.

\subsection{Hydrogen Sulfide in Cancer Metastasis}

Cancer metastasis is an important milestone during cancer development, in which cancer cells invade surrounding tissues, spread to distant sites, and grow secondary tumors in another part of the body [104]. The initial development of cancer metastasis requires cancer cells to gain migration and invasion ability through epithelial to mesenchymal transition (EMT) [125]. Endogenous $\mathrm{H}_{2} \mathrm{~S}$ promotes cancer cell migration and invasion in multiple cancer types, such as prostate cancer [45], lung cancer [101], colon cancer [95,126], and liver cancer [109], partly through induction of ATP citrate lyase (ACLY) to facilitate EMT [95]. Moreover, NF-kB, a key molecule driving cancer metastasis [111], is involved in the $\mathrm{H}_{2} \mathrm{~S}$-modulated cancer metastasis through persulfidation. Persulfidation at $\mathrm{Cys}^{38}$ of the NF- $\mathrm{kB}$ p65 subunit facilitates nuclear translocation of p65 and then induces expressions 
of metastatic promoting genes, especially IL-1 $\beta$, resulting in enhanced cell invasion and distant metastasis during prostate cancer progression [45].

\subsection{Hydrogen Sulfide in Angiogenesis}

Angiogenesis is the formation of new blood vessels from the pre-existing vasculature [127]. During cancer development, tumor cells secrete pro-angiogenic factors, such as VEGF, to support tumor growth and stimulate distant metastases [127]. Numerous studies already confirmed that $\mathrm{H}_{2} \mathrm{~S}$ acts as a pro-angiogenic factor in vitro and in vivo under different physiological and disease conditions, including cancer [102]. Silencing $\mathrm{H}_{2} \mathrm{~S}$ producing enzyme, CBS, reduces the formation of tumor blood vessels in colon cancer $[17,57]$ and ovarian cancer [58]. Depletion of another $\mathrm{H}_{2} \mathrm{~S}$ producing enzyme, $\mathrm{CTH}$, not only blocks angiogenesis $[30,45]$ but also lymphangiogenesis [45]. Moreover, $\mathrm{H}_{2} \mathrm{~S}$ promotes hypoxia-induced angiogenesis through induction of HIF-1 $\alpha$ as we previously discussed in Section 4.4.

Although $\mathrm{H}_{2} \mathrm{~S}$ is an endogenous stimulator of angiogenesis through activation of PI3K/AKT and MAPK signaling pathway [30], the underlying mechanism remains unclear. One possibility is $\mathrm{H}_{2} \mathrm{~S}$ may mediate angiogenesis through persulfidation of Kir6.1 subunit of KATP channel at $\mathrm{Cys}^{43}$ [3] since pharmacological inhibition of KATP channel attenuates VEGF mediated endothelial cell migration [30]. The other possibility is through $\mathrm{H}_{2} \mathrm{~S}$ mediated persulfidation of NF- $\mathrm{kB}$ p 65 subunit and subsequent activation of NF- $\mathrm{KB} / \mathrm{IL}-1 \beta$ signaling [45] since IL- $1 \beta$ is a known pro-angiogenic cytokine during cancer progression through induction of VEGF $[57,128]$. More research will be needed to decipher how $\mathrm{H}_{2} \mathrm{~S}$ impacts angiogenesis during cancer development.

\section{Hydrogen Sulfide Based Therapeutics}

Upregulation of $\mathrm{H}_{2} \mathrm{~S}$ producing enzymes and increased endogenous $\mathrm{H}_{2} \mathrm{~S}$ production are recognized in many cancer types, which in turn promotes cancer progression. However, donors producing a higher level of $\mathrm{H}_{2} \mathrm{~S}$ are considered as anti-cancer drugs [129] through induction of uncontrolled intracellular acidification [130], resulting in the promotion of apoptosis [131-136] and cell cycle arrest $[131,133,137,138]$. The controversial role of $\mathrm{H}_{2} \mathrm{~S}$ in cancer research field can be explained by the bell-shaped (biphasic) model, in which Hellmich and Szabo suggested that lower concentrations of $\mathrm{H}_{2} \mathrm{~S}$ display pro-cancer effects while higher concentrations exhibit anti-cancer properties [55,139]. In that sense, both $\mathrm{H}_{2} \mathrm{~S}$ inhibitors and donors show some potential on cancer therapy.

The donors of $\mathrm{H}_{2} \mathrm{~S}$ include sulfide salts, such as sodium hydrosulfide (NaHS) and sodium sulfide $\left(\mathrm{Na}_{2} \mathrm{~S}\right)$, which release $\mathrm{H}_{2} \mathrm{~S}$ directly. Other $\mathrm{H}_{2} \mathrm{~S}$ donors are categorized by their release mechanisms. Donation of $\mathrm{H}_{2} \mathrm{~S}$ can be triggered by hydrolysis, reactive oxygen species (ROS), biological thiols, specific wavelengths of light, and enzymes [140-143]. Various $\mathrm{H}_{2} \mathrm{~S}$ donors have been synthesized and tested preclinically to kill cancer cells at high doses and/or long-term exposure [131,133,135,144-147]. A slow-releasing $\mathrm{H}_{2} \mathrm{~S}$ donor, GYY4137, enhances glucose uptake, glycolysis, and lactate production while decreasing the activity of $\mathrm{pH}$ regulators, anion exchanger (AE), and sodium/proton exchanger (NHE), resulting in the intracellular acidification in cancer cells [130]. Moreover, GYY4137 blocks STAT3 signaling, leading to the cell cycle arrest, apoptosis, and inhibition of hepatocellular carcinoma tumor growth [133]. Other $\mathrm{H}_{2} \mathrm{~S}$ donors, diallyl trisulfide (DATS) and 5-(4hydroxyphenyl)-3H-1,2-dithiole-3-thione (ADT-OH), are also effective in the suppression of tumor growth through inhibition of NF- $\mathrm{KB}$ activity and upregulation of Fas-associated protein with death domain (FADD) in melanoma $[134,136]$. However, the toxicity of these $\mathrm{H}_{2} \mathrm{~S}$ donors in normal cells are the major concerns for the current drug development.

In contrast to $\mathrm{H}_{2} \mathrm{~S}$ donors, options to inhibit endogenous $\mathrm{H}_{2} \mathrm{~S}$ production are very limited. Currently, there are only inhibitors for CTH and CBS, both are PLP-dependent enzymes. The most frequently used inhibitor, DL-propargylglycine (PAG) [148], is an irreversible inhibitor of CTH with IC50 at $40 \mu \mathrm{M}$ and displays high selectivity for CTH over CBS [149]. However, PAG is typically used at millimolar concentrations, in cell-based 
assays [30,64,69,150-152], due to limited cell permeability [153]. Studies have confirmed that millimolar concentration of PAG results in the non-selective inhibition on enzymes other than CTH [154-156]. The other frequently used inhibitor is aminooxyacetic acid (AOAA), which inhibits both CBS and CTH and shows higher potency against CTH (IC50 at $1.1 \mu \mathrm{M})$ than CBS(IC50 at $8.5 \mu \mathrm{M})$ [149]. Additionally, AOAA is a general inhibitor of several other PLP-dependent enzymes [157] including cysteine aminotransferase (CAT), which catalyzes the transamination between L-cysteine and $\alpha$-ketoglutarate $(\alpha-\mathrm{KG})$ to produce 3-mercaptopyruvate (3-MP), a substrate for 3-MST (Figure 2) [158]. Furthermore, AOAA inhibits non-enzymatic $\mathrm{H}_{2} \mathrm{~S}$ production catalyzed by iron $\left(\mathrm{Fe}^{3+}\right)$ and PLP [159]. As the result, AOAA suppresses $\mathrm{H}_{2} \mathrm{~S}$ production through all enzymatic and non-enzymatic pathways. There are several additional molecules that selectively inhibit activities of CBS [160-164] or CTH [165-169] to exert anticancer effect. On the other hand, there was no selective inhibitor for 3-MST until recently, Hanaoka, K. et al. (2017) established a highthroughput screening (HTS) method to screen 174,118 compounds and several potential inhibitors for 3-MST were identified. Among them, 2-[(4-hydroxy-6-methylpyrimidin2-yl)sulfanyl]-1-(naphthalen-1-yl)ethan-1-one (HMPSNE) showed the highest selectivity for 3-MST [170-172] and dose-dependently inhibited cell proliferation in colon cancer cell [94]. In a more recent study, derivative of HMPSNE was synthesized and exerted antiproliferative effect in vitro and in vivo in colon cancer model through targeting 3MST [173]. More investigations will be needed to confirm their potency and efficacy in the inhibition of $\mathrm{H}_{2} \mathrm{~S}$ production.

\section{Conclusions}

Given the fact that the importance of $\mathrm{H}_{2} \mathrm{~S}$-mediated persulfidation in protein functions, it is not surprising that aberrant expressions of $\mathrm{H}_{2} \mathrm{~S}$ producing enzymes can contribute to cancer development from different aspects, including anti-apoptosis, DNA repair, tumor growth, cancer metabolism, metastasis, and angiogenesis (Figure 3). However, right now there are only very limited and non-specific options available for pharmacological inhibitors to suppress $\mathrm{H}_{2} \mathrm{~S}$ production. For future perspectives, we hope more $\mathrm{H}_{2} \mathrm{~S}$-targeted signaling molecules will be identified and pharmacological inhibitors with high selectivity and potency will be developed to improve the future experimental therapy of cancer.

Author Contributions: All authors contributed to the writing and reviewing of the manuscript. All authors have read and agreed to the published version of the manuscript.

Funding: This APC was supported by Ministry of Science and Technology (MOST), Taiwan (MOST 108-2314-B-007-003-MY3) and National Tsing-Hua University (110Q2705E1 and 110Q2729E1).

Institutional Review Board Statement: Not applicable.

Informed Consent Statement: Not applicable.

Data Availability Statement: Not applicable.

Conflicts of Interest: The authors declare no conflict of interest.

\section{References}

1. Wang, R. Two's company, three's a crowd: Can $\mathrm{H}_{2} \mathrm{~S}$ be the third endogenous gaseous transmitter? FASEB J. 2002, 16, 1792-1798. [CrossRef]

2. Yang, G.; Wu, L.; Jiang, B.; Yang, W.; Qi, J.; Cao, K.; Meng, Q.; Mustafa, A.K.; Mu, W.; Zhang, S.; et al. H ${ }_{2} \mathrm{~S}$ as a physiologic vasorelaxant: Hypertension in mice with deletion of cystathionine gamma-lyase. Science 2008, 322, 587-590. [CrossRef] [PubMed]

3. Mustafa, A.K.; Sikka, G.; Gazi, S.K.; Steppan, J.; Jung, S.M.; Bhunia, A.K.; Barodka, V.M.; Gazi, F.K.; Barrow, R.K.; Wang, R.; et al. Hydrogen sulfide as endothelium-derived hyperpolarizing factor sulfhydrates potassium channels. Circ. Res. 2011, 109, 1259-1268. [CrossRef]

4. Coletta, C.; Papapetropoulos, A.; Erdelyi, K.; Olah, G.; Modis, K.; Panopoulos, P.; Asimakopoulou, A.; Gero, D.; Sharina, I.; Martin, E.; et al. Hydrogen sulfide and nitric oxide are mutually dependent in the regulation of angiogenesis and endotheliumdependent vasorelaxation. Proc. Natl. Acad. Sci. USA 2012, 109, 9161-9166. [CrossRef] [PubMed]

5. Nicholson, C.K.; Calvert, J.W. Hydrogen sulfide and ischemia-reperfusion injury. Pharmacol. Res. 2010, 62, 289-297. [CrossRef] 
6. Zanardo, R.C.; Brancaleone, V.; Distrutti, E.; Fiorucci, S.; Cirino, G.; Wallace, J.L. Hydrogen sulfide is an endogenous modulator of leukocyte-mediated inflammation. FASEB J. 2006, 20, 2118-2120. [CrossRef]

7. Shibuya, N.; Mikami, Y.; Kimura, Y.; Nagahara, N.; Kimura, H. Vascular endothelium expresses 3-mercaptopyruvate sulfurtransferase and produces hydrogen sulfide. J. Biochem. 2009, 146, 623-626. [CrossRef]

8. Ramazzini, B. De morbis artificum diatriba 1743. Am. J. Public Health 2001, 91, 1380-1382. [CrossRef] [PubMed]

9. Mitchell, C.W.; Davenport, S.J. Hydrogen sulphide literature. Public Health Rep. 1924, 39, 1-13. [CrossRef]

10. Reiffenstein, R.; Hulbert, W.C.; Roth, S.H. Toxicology of hydrogen sulfide. Annu. Rev. Pharmacol. Toxicol. 1992, 32, 109-134. [CrossRef]

11. Rubright, S.L.M.; Pearce, L.L.; Peterson, J. Environmental toxicology of hydrogen sulfide. Nitric Oxide Biol. Chem. 2017, 71, 1-13. [CrossRef] [PubMed]

12. Clarke, P.H. Hydrogen sulphide production by bacteria. Microbiology 1953, 8, 397-407. [CrossRef]

13. Aroca, Á.; Serna, A.; Gotor, C.; Romero, L.C. S-sulfhydration: A cysteine posttranslational modification in plant systems. Plant. Physiol. 2015, 168, 334-342. [CrossRef] [PubMed]

14. Aroca, A.; Gotor, C.; Romero, L.C. Hydrogen sulfide signaling in plants: Emerging roles of protein persulfidation. Front. Plant Sci. 2018, 9, 1369. [CrossRef] [PubMed]

15. Kamoun, P. Endogenous production of hydrogen sulfide in mammals. Amino Acids 2004, 26, 243-254. [CrossRef]

16. Shibuya, N.; Koike, S.; Tanaka, M.; Ishigami-Yuasa, M.; Kimura, Y.; Ogasawara, Y.; Fukui, K.; Nagahara, N.; Kimura, H. A novel pathway for the production of hydrogen sulfide from D-cysteine in mammalian cells. Nat. Commun. 2013, 4, 1-7. [CrossRef]

17. Abe, K.; Kimura, H. The possible role of hydrogen sulfide as an endogenous neuromodulator. J. Neurosci. 1996, 16, 1066-1071. [CrossRef]

18. Szabo, C. Gasotransmitters in cancer: From pathophysiology to experimental therapy. Nat. Rev. Drug Discov. 2016, 15, 185-203. [CrossRef]

19. Mustafa, A.K.; Gadalla, M.M.; Snyder, S.H. Signaling by gasotransmitters. Sci. Signal. 2009, 2, re2. [CrossRef]

20. Hosoki, R.; Matsuki, N.; Kimura, H. The possible role of hydrogen sulfide as an endogenous smooth muscle relaxant in synergy with nitric oxide. Biochem. Biophys. Res. Commun. 1997, 237, 527-531. [CrossRef]

21. Di Villa Bianca, R.d.E.; Sorrentino, R.; Maffia, P.; Mirone, V.; Imbimbo, C.; Fusco, F.; De Palma, R.; Ignarro, L.J.; Cirino, G. Hydrogen sulfide as a mediator of human corpus cavernosum smooth-muscle relaxation. Proc. Natl. Acad. Sci. USA 2009, 106, 4513-4518. [CrossRef]

22. Geng, B.; Chang, L.; Pan, C.; Qi, Y.; Zhao, J.; Pang, Y.; Du, J.; Tang, C. Endogenous hydrogen sulfide regulation of myocardial injury induced by isoproterenol. Biochem. Biophys. Res. Commun. 2004, 318, 756-763. [CrossRef]

23. Elrod, J.W.; Calvert, J.W.; Morrison, J.; Doeller, J.E.; Kraus, D.W.; Tao, L.; Jiao, X.; Scalia, R.; Kiss, L.; Szabo, C. Hydrogen sulfide attenuates myocardial ischemia-reperfusion injury by preservation of mitochondrial function. Proc. Natl. Acad. Sci. USA 2007, 104, 15560-15565. [CrossRef] [PubMed]

24. Guo, C.; Liang, F.; Masood, W.S.; Yan, X. Hydrogen sulfide protected gastric epithelial cell from ischemia/reperfusion injury by Keap1 s-sulfhydration, MAPK dependent anti-apoptosis and NF-kB dependent anti-inflammation pathway. Eur. J. Pharmacol. 2014, 725, 70-78. [CrossRef] [PubMed]

25. Kimura, Y.; Kimura, H. Hydrogen sulfide protects neurons from oxidative stress. FASEB J. 2004, 18, 1165-1167. [CrossRef] [PubMed]

26. Kimura, Y.; Dargusch, R.; Schubert, D.; Kimura, H. Hydrogen sulfide protects HT22 neuronal cells from oxidative stress. Antioxid. Redox Signal. 2006, 8, 661-670. [CrossRef]

27. Hu, L.F.; Lu, M.; Tiong, C.X.; Dawe, G.S.; Hu, G.; Bian, J.S. Neuroprotective effects of hydrogen sulfide on Parkinson's disease rat models. Aging Cell 2010, 9, 135-146. [CrossRef] [PubMed]

28. Li, L.; Bhatia, M.; Zhu, Y.Z.; Zhu, Y.C.; Ramnath, R.D.; Wang, Z.J.; Anuar, F.B.M.; Whiteman, M.; Salto-Tellez, M.; Moore, P.K. Hydrogen sulfide is a novel mediator of lipopolysaccharide-induced inflammation in the mouse. FASEB J. 2005, 19, 1196-1198. [CrossRef] [PubMed]

29. Whiteman, M.; Winyard, P.G. Hydrogen sulfide and inflammation: The good, the bad, the ugly and the promising. Expert Rev. Clin. Pharmacol. 2011, 4, 13-32. [CrossRef]

30. Papapetropoulos, A.; Pyriochou, A.; Altaany, Z.; Yang, G.; Marazioti, A.; Zhou, Z.; Jeschke, M.G.; Branski, L.K.; Herndon, D.N.; Wang, R.; et al. Hydrogen sulfide is an endogenous stimulator of angiogenesis. Proc. Natl. Acad. Sci. USA 2009, 106, $21972-21977$. [CrossRef]

31. Katsouda, A.; Bibli, S.-I.; Pyriochou, A.; Szabo, C.; Papapetropoulos, A. Regulation and role of endogenously produced hydrogen sulfide in angiogenesis. Pharmacol. Res. 2016, 113, 175-185. [CrossRef]

32. Krishnan, N.; Fu, C.; Pappin, D.J.; Tonks, N.K. H2S-Induced sulfhydration of the phosphatase PTP1B and its role in the endoplasmic reticulum stress response. Sci. Signal. 2011, 4, ra86. [CrossRef]

33. Sen, N.; Paul, B.D.; Gadalla, M.M.; Mustafa, A.K.; Sen, T.; Xu, R.; Kim, S.; Snyder, S.H. Hydrogen sulfide-linked sulfhydration of NF- $\mathrm{kB}$ mediates its antiapoptotic actions. Mol. Cell 2012, 45, 13-24. [CrossRef] [PubMed]

34. Yang, G.; Zhao, K.; Ju, Y.; Mani, S.; Cao, Q.; Puukila, S.; Khaper, N.; Wu, L.; Wang, R. Hydrogen sulfide protects against cellular senescence via S-sulfhydration of Keap1 and activation of Nrf2. Antioxid. Redox Signal. 2013, 18, 1906-1919. [CrossRef] 
35. Liu, Y.; Yang, R.; Liu, X.; Zhou, Y.; Qu, C.; Kikuiri, T.; Wang, S.; Zandi, E.; Du, J.; Ambudkar, I.S. Hydrogen sulfide maintains mesenchymal stem cell function and bone homeostasis via regulation of Ca2+ channel sulfhydration. Cell Stem Cell 2014, 15, 66-78. [CrossRef]

36. Zhao, K.; Ju, Y.; Li, S.; Altaany, Z.; Wang, R.; Yang, G. S-sulfhydration of MEK 1 leads to PARP-1 activation and DNA damage repair. EMBO Rep. 2014, 15, 792-800. [CrossRef]

37. Ju, Y.; Untereiner, A.; Wu, L.; Yang, G. H2S-induced S-sulfhydration of pyruvate carboxylase contributes to gluconeogenesis in liver cells. Biochim. Biophys. Acta Gen. Subj. 2015, 1850, 2293-2303. [CrossRef] [PubMed]

38. Xie, L.; Gu, Y.; Wen, M.; Zhao, S.; Wang, W.; Ma, Y.; Meng, G.; Han, Y.; Wang, Y.; Liu, G. Hydrogen sulfide induces Keap1 S-sulfhydration and suppresses diabetes-accelerated atherosclerosis via Nrf2 activation. Diabetes 2016, 65, 3171-3184. [CrossRef]

39. Zheng, Y.; Liao, F.; Lin, X.; Zheng, F.; Fan, J.; Cui, Q.; Yang, J.; Geng, B.; Cai, J. Cystathionine $\gamma$-Lyase-Hydrogen Sulfide Induces Runt-Related Transcription Factor 2 Sulfhydration, Thereby Increasing Osteoblast Activity to Promote Bone Fracture Healing. Antioxid. Redox Signal. 2017, 27, 742-753. [CrossRef] [PubMed]

40. Wu, D.; Hu, Q.; Tan, B.; Rose, P.; Zhu, D.; Zhu, Y.Z. Amelioration of mitochondrial dysfunction in heart failure through S-sulfhydration of Ca2+/calmodulin-dependent protein kinase II. Redox Biol. 2018, 19, 250-262. [CrossRef]

41. Yuan, Y.; Zhu, L.; Li, L.; Liu, J.; Chen, Y.; Cheng, J.; Peng, T.; Lu, Y. S-Sulfhydration of SIRT3 by hydrogen sulfide attenuates mitochondrial dysfunction in cisplatin-induced acute kidney injury. Antioxid. Redox Signal. 2019, 31, 1302-1319. [CrossRef] [PubMed]

42. Zhao, S.; Song, T.; Gu, Y.; Zhang, Y.; Cao, S.; Miao, Q.; Zhang, X.; Chen, H.; Gao, Y.; Zhang, L. Hydrogen sulfide alleviates liver injury via S-sulfhydrated-Keap1/Nrf2/LRP1 pathway. Hepatology 2020. [CrossRef]

43. Sun, X.; Zhao, D.; Lu, F.; Peng, S.; Yu, M.; Liu, N.; Sun, Y.; Du, H.; Wang, B.; Chen, J. Hydrogen sulfide regulates muscle RING finger-1 protein S-sulfhydration at Cys44 to prevent cardiac structural damage in diabetic cardiomyopathy. Br. J. Pharmacol. 2020, 177, 836-856. [CrossRef] [PubMed]

44. Sun, H.-J.; Xiong, S.-P.; Cao, X.; Cao, L.; Zhu, M.-Y.; Wu, Z.-Y.; Bian, J.-S. Polysulfide-mediated sulfhydration of SIRT1 prevents diabetic nephropathy by suppressing phosphorylation and acetylation of p65 NF-кB and STAT3. Redox Biol. 2021, $38,101813$. [CrossRef] [PubMed]

45. Wang, Y.H.; Huang, J.T.; Chen, W.L.; Wang, R.H.; Kao, M.C.; Pan, Y.R.; Chan, S.H.; Tsai, K.W.; Kung, H.J.; Lin, K.T. Dysregulation of cystathionine $\gamma$-lyase promotes prostate cancer progression and metastasis. EMBO Rep. 2019, 20, e45986. [CrossRef]

46. Mustafa, A.K.; Gadalla, M.M.; Sen, N.; Kim, S.; Mu, W.; Gazi, S.K.; Barrow, R.K.; Yang, G.; Wang, R.; Snyder, S.H. H 2 S signals through protein S-sulfhydration. Sci. Signal. 2009, 2, ra72. [CrossRef]

47. Zhang, D.; Macinkovic, I.; Devarie-Baez, N.O.; Pan, J.; Park, C.M.; Carroll, K.S.; Filipovic, M.R.; Xian, M. Detection of protein S-sulfhydration by a tag-switch technique. Angew. Chem. Int. Ed. 2014, 53, 575-581. [CrossRef]

48. Gupta, V.; Carroll, K.S. Sulfenic acid chemistry, detection and cellular lifetime. Biochim. Biophys. Acta Gen. Subj. 2014, 1840, 847-875. [CrossRef]

49. Hess, D.T.; Stamler, J.S. Regulation by S-nitrosylation of protein post-translational modification. J. Biol. Chem. 2012, 287, 4411-4418. [CrossRef]

50. Francoleon, N.E.; Carrington, S.J.; Fukuto, J.M. The reaction of H2S with oxidized thiols: Generation of persulfides and implications to H2S biology. Arch. Biochem. Biophys. 2011, 516, 146-153. [CrossRef]

51. Wedmann, R.; Bertlein, S.; Macinkovic, I.; Böltz, S.; Miljkovic, J.L.; Muñoz, L.E.; Herrmann, M.; Filipovic, M.R. Working with " $\mathrm{H}_{2} \mathrm{~S}$ ": Facts and apparent artifacts. Nitric Oxide 2014, 41, 85-96. [CrossRef] [PubMed]

52. Miljkovic, J.L.; Kenkel, I.; Ivanović-Burmazović, I.; Filipovic, M.R. Generation of HNO and HSNO from nitrite by heme-ironcatalyzed metabolism with H2S. Angew. Chem. Int. Ed. 2013, 52, 12061-12064. [CrossRef]

53. Greiner, R.; Pálinkás, Z.; Bäsell, K.; Becher, D.; Antelmann, H.; Nagy, P.; Dick, T.P. Polysulfides link H2S to protein thiol oxidation. Antioxid. Redox Signal. 2013, 19, 1749-1765. [CrossRef]

54. Ida, T.; Sawa, T.; Ihara, H.; Tsuchiya, Y.; Watanabe, Y.; Kumagai, Y.; Suematsu, M.; Motohashi, H.; Fujii, S.; Matsunaga, T. Reactive cysteine persulfides and S-polythiolation regulate oxidative stress and redox signaling. Proc. Natl. Acad. Sci. USA 2014, 111, 7606-7611. [CrossRef] [PubMed]

55. Hellmich, M.R.; Szabo, C. Hydrogen sulfide and cancer. Chem. Biochem. Pharmacol. Hydrog. Sulfide 2015, $233-241$.

56. Giuffrè, A.; Tomé, C.S.; Fernandes, D.G.; Zuhra, K.; Vicente, J.B. Hydrogen sulfide metabolism and signaling in the tumor microenvironment. Tumor Microenviron. 2020, 1219, 335-353.

57. Szabo, C.; Coletta, C.; Chao, C.; Módis, K.; Szczesny, B.; Papapetropoulos, A.; Hellmich, M.R. Tumor-derived hydrogen sulfide, produced by cystathionine- $\beta$-synthase, stimulates bioenergetics, cell proliferation, and angiogenesis in colon cancer. Proc. Natl. Acad. Sci. USA 2013, 110, 12474-12479. [CrossRef]

58. Bhattacharyya, S.; Saha, S.; Giri, K.; Lanza, I.R.; Nair, K.S.; Jennings, N.B.; Rodriguez-Aguayo, C.; Lopez-Berestein, G.; Basal, E.; Weaver, A.L. Cystathionine beta-synthase (CBS) contributes to advanced ovarian cancer progression and drug resistance. PLoS ONE 2013, 8, e79167. [CrossRef]

59. Sen, S.; Kawahara, B.; Gupta, D.; Tsai, R.; Khachatryan, M.; Roy-Chowdhuri, S.; Bose, S.; Yoon, A.; Faull, K.; Farias-Eisner, R. Role of cystathionine $\beta$-synthase in human breast Cancer. Free Radic. Biol. Med. 2015, 86, 228-238. [CrossRef]

60. Turbat-Herrera, E.A.; Kilpatrick, M.J.; Chen, J.; Meram, A.T.; Cotelingam, J.; Ghali, G.; Kevil, C.G.; Coppola, D.; Shackelford, R.E. Cystathione $\beta$-synthase is increased in thyroid malignancies. Anticancer Res. 2018, 38, 6085-6090. [CrossRef] 
61. Li, D.; Yang, Z.; Liu, Z.; Zou, Q.; Yuan, Y. Clinical significance of CBS and CCL21 in gallbladder adenocarcinomas and squamous cell/adenosquamous carcinomas. Appl. Immunohistochem. Mol. Morphol. 2020, 28, 103-110. [CrossRef]

62. Kim, J.; Hong, S.J.; Park, J.H.; Park, S.Y.; Kim, S.W.; Cho, E.Y.; Do, I.-G.; Joh, J.-W.; Kim, D.S. Expression of cystathionine $\beta$-synthase is downregulated in hepatocellular carcinoma and associated with poor prognosis. Oncol. Rep. 2009, 21, 1449-1454. [CrossRef]

63. Zhao, H.; Li, Q.; Wang, J.; Su, X.; Ng, K.M.; Qiu, T.; Shan, L.; Ling, Y.; Wang, L.; Cai, J. Frequent epigenetic silencing of the folate-metabolising gene cystathionine-beta-synthase in gastrointestinal cancer. PLoS ONE 2012, 7, e49683. [CrossRef]

64. You, J.; Shi, X.; Liang, H.; Ye, J.; Wang, L.; Han, H.; Fang, H.; Kang, W.; Wang, T. Cystathionine- $\gamma$-lyase promotes process of breast cancer in association with STAT3 signaling pathway. Oncotarget 2017, 8, 65677. [CrossRef]

65. Pei, Y.; Wu, B.; Cao, Q.; Wu, L.; Yang, G. Hydrogen sulfide mediates the anti-survival effect of sulforaphane on human prostate cancer cells. Toxicol. Appl. Pharmacol. 2011, 257, 420-428. [CrossRef] [PubMed]

66. Zhang, L.; Qi, Q.; Yang, J.; Sun, D.; Li, C.; Xue, Y.; Jiang, Q.; Tian, Y.; Xu, C.; Wang, R. An anticancer role of hydrogen sulfide in human gastric cancer cells. Oxidative Med. Cell. Longev. 2015. [CrossRef] [PubMed]

67. Gai, J.-W.; Qin, W.; Liu, M.; Wang, H.-F.; Zhang, M.; Li, M.; Zhou, W.-H.; Ma, Q.-T.; Liu, G.-M.; Song, W.-H. Expression Profile of Hydrogen Sulfide and Its Synthases Correlates with Tumor Stage and Grade in Urothelial Cell Carcinoma of Bladder. In Urologic Oncology: Seminars and Original Investigations; Elsevier: Amsterdam, The Netherlands, 2016; pp. 166.e15-166.e20.

68. Pan, Y.; Ye, S.; Yuan, D.; Zhang, J.; Bai, Y.; Shao, C. Hydrogen sulfide $\left(\mathrm{H}_{2} \mathrm{~S}\right)$ / cystathionine $\gamma$-lyase (CSE) pathway contributes to the proliferation of hepatoma cells. Mutat. Res. Mol. Mech. Mutagen. 2014, 763, 10-18. [CrossRef] [PubMed]

69. Fan, K.; Li, N.; Qi, J.; Yin, P.; Zhao, C.; Wang, L.; Li, Z.; Zha, X. Wnt/ $\beta$-catenin signaling induces the transcription of cystathionine$\gamma$-lyase, a stimulator of tumor in colon cancer. Cell. Signal. 2014, 26, 2801-2808. [CrossRef] [PubMed]

70. Breza, J., Jr.; Soltysova, A.; Hudecova, S.; Penesova, A.; Szadvari, I.; Babula, P.; Chovancova, B.; Lencesova, L.; Pos, O.; Breza, J.; et al. Endogenous $\mathrm{H}_{2} \mathrm{~S}$ producing enzymes are involved in apoptosis induction in clear cell renal cell carcinoma. BMC Cancer 2018, 18, 591. [CrossRef]

71. Wrobel, M.; Czubak, J.; Bronowicka-Adamska, P.; Jurkowska, H.; Adamek, D.; Papla, B. Is development of high-grade gliomas sulfur-dependent? Molecules 2014, 19, 21350-21362. [CrossRef]

72. Olah, G.; Modis, K.; Toro, G.; Hellmich, M.R.; Szczesny, B.; Szabo, C. Role of endogenous and exogenous nitric oxide, carbon monoxide and hydrogen sulfide in HCT116 colon cancer cell proliferation. Biochem. Pharmacol. 2018, 149, 186-204. [CrossRef]

73. Cao, X.; Ding, L.; Xie, Z.-Z.; Yang, Y.; Whiteman, M.; Moore, P.K.; Bian, J.-S. A review of hydrogen sulfide synthesis, metabolism, and measurement: Is modulation of hydrogen sulfide a novel therapeutic for cancer? Antioxid. Redox Signal. 2019, 31, 1-38. [CrossRef] [PubMed]

74. Murphy, B.; Bhattacharya, R.; Mukherjee, P. Hydrogen sulfide signaling in mitochondria and disease. FASEB J. 2019, 33, 13098-13125. [CrossRef] [PubMed]

75. Kabil, O.; Zhou, Y.; Banerjee, R. Human cystathionine $\beta$-synthase is a target for sumoylation. Biochemistry 2006, 45, 13528-13536. [CrossRef]

76. Agrawal, N.; Banerjee, R. Human polycomb 2 protein is a SUMO E3 ligase and alleviates substrate-induced inhibition of cystathionine $\beta$-synthase sumoylation. PLoS ONE 2008, 3, e4032. [CrossRef]

77. Niu, W.-N.; Yadav, P.K.; Adamec, J.; Banerjee, R. S-glutathionylation enhances human cystathionine $\beta$-synthase activity under oxidative stress conditions. Antioxid. Redox Signal. 2015, 22, 350-361. [CrossRef] [PubMed]

78. Di Villa Bianca, R.d.E.; Mitidieri, E.; Esposito, D.; Donnarumm, E.; Russo, A.; Fusco, F.; Ianaro, A.; Mirone, V.; Cirino, G.; Russo, G. Human cystathionine- $\beta$-synthase phosphorylation on serine 227 modulates hydrogen sulfide production in human urothelium. PLOS ONE 2015, 10, e0136859.

79. Singh, S.; Madzelan, P.; Banerjee, R. Properties of an unusual heme cofactor in PLP-dependent cystathionine $\beta$-synthase. Nat. Prod. Rep. 2007, 24, 631-639. [CrossRef]

80. Tu, X.; Huang, S.; Li, W.; Song, J. Correlation of methylation of CpG island in cystathionine beta synthase promoter and clinicopathological features in colorectal cancer. Chin. J. Oncol. 2013, 35, 351-355.

81. Ereño-Orbea, J.; Majtan, T.; Oyenarte, I.; Kraus, J.P.; Martínez-Cruz, L.A. Structural insight into the molecular mechanism of allosteric activation of human cystathionine $\beta$-synthase by S-adenosylmethionine. Proc. Natl. Acad. Sci. USA 2014, 111, E3845-E3852. [CrossRef]

82. Prudova, A.; Bauman, Z.; Braun, A.; Vitvitsky, V.; Lu, S.C.; Banerjee, R. S-adenosylmethionine stabilizes cystathionine $\beta$-synthase and modulates redox capacity. Proc. Natl. Acad. Sci. USA 2006, 103, 6489-6494. [CrossRef]

83. Módis, K.; Coletta, C.; Asimakopoulou, A.; Szczesny, B.; Chao, C.; Papapetropoulos, A.; Hellmich, M.R.; Szabo, C. Effect of S-adenosyl-L-methionine (SAM), an allosteric activator of cystathionine- $\beta$-synthase (CBS) on colorectal cancer cell proliferation and bioenergetics in vitro. Nitric Oxide 2014, 41, 146-156. [CrossRef] [PubMed]

84. Niu, W.; Wang, J.; Qian, J.; Wang, M.; Wu, P.; Chen, F.; Yan, S. Allosteric control of human cystathionine $\beta$-synthase activity by a redox active disulfide bond. J. Biol. Chem. 2018, 293, 2523-2533. [CrossRef] [PubMed]

85. Takano, N.; Sarfraz, Y.; Gilkes, D.M.; Chaturvedi, P.; Xiang, L.; Suematsu, M.; Zagzag, D.; Semenza, G.L. Decreased expression of cystathionine $\beta$-synthase promotes glioma tumorigenesis. Mol. Cancer Res. 2014, 12, 1398-1406. [CrossRef]

86. Kimura, Y.; Toyofuku, Y.; Koike, S.; Shibuya, N.; Nagahara, N.; Lefer, D.; Ogasawara, Y.; Kimura, H. Identification of $\mathrm{H}_{2} \mathrm{~S}_{3}$ and $\mathrm{H}_{2} \mathrm{~S}$ produced by 3-mercaptopyruvate sulfurtransferase in the brain. Sci. Rep. 2015, 5, 14774. [CrossRef] [PubMed] 
87. Jurkowska, H.; Placha, W.; Nagahara, N.; Wróbel, M. The expression and activity of cystathionine- $\gamma$-lyase and 3-mercaptopyruvate sulfurtransferase in human neoplastic cell lines. Amino Acids 2011, 41, 151-158. [CrossRef]

88. Sbodio, J.I.; Snyder, S.H.; Paul, B.D. Regulators of the transsulfuration pathway. Br. J. Pharmacol 2019, 176, 583-593. [CrossRef] [PubMed]

89. He, F.; Ru, X.; Wen, T. NRF2, a transcription factor for stress response and beyond. Int. J. Mol. Sci. 2020, 21, 4777. [CrossRef]

90. Hourihan, J.M.; Kenna, J.G.; Hayes, J.D. The gasotransmitter hydrogen sulfide induces nrf2-target genes by inactivating the keap1 ubiquitin ligase substrate adaptor through formation of a disulfide bond between cys-226 and cys-613. Antioxid. Redox Signal. 2013, 19, 465-481. [CrossRef]

91. Yang, G.; Pei, Y.; Teng, H.; Cao, Q.; Wang, R. Specificity protein-1 as a critical regulator of human cystathionine $\gamma$-lyase in smooth muscle cells. J. Biol. Chem. 2011, 286, 26450-26460. [CrossRef] [PubMed]

92. Nagahara, N.; Katayama, A. Post-translational regulation of mercaptopyruvate sulfurtransferase via a low redox potential cysteine-sulfenate in the maintenance of redox homeostasis. J. Biol. Chem. 2005, 280, 34569-34576. [CrossRef] [PubMed]

93. Nagahara, N. Multiple role of 3-mercaptopyruvate sulfurtransferase: Antioxidative function, $\mathrm{H}_{2} \mathrm{~S}$ and polysulfide production and possible SOx production. Br. J. Pharmacol. 2018, 175, 577-589. [CrossRef]

94. Augsburger, F.; Randi, E.B.; Jendly, M.; Ascencao, K.; Dilek, N.; Szabo, C. Role of 3-mercaptopyruvate sulfurtransferase in the regulation of proliferation, migration, and bioenergetics in murine colon cancer cells. Biomolecules 2020, 10, 447. [CrossRef] [PubMed]

95. Ascencao, K.; Dilek, N.; Augsburger, F.; Panagaki, T.; Zuhra, K.; Szabo, C. Pharmacological induction of mesenchymal-epithelial transition via inhibition of H2S biosynthesis and consequent suppression of ACLY activity in colon cancer cells. Pharmacol. Res. 2021, 165, 105393. [CrossRef]

96. Hockel, M.; Vaupel, P. Tumor hypoxia: Definitions and current clinical, biologic, and molecular aspects. J. Natl. Cancer Inst. 2001, 93, 266-276. [CrossRef]

97. Cao, X.; Bian, J.-S. The role of hydrogen sulfide in renal system. Front. Pharmacol. 2016, 7, 385. [CrossRef]

98. Wang, M.; Guo, Z.; Wang, S. Regulation of cystathionine $\gamma$-lyase in mammalian cells by hypoxia. Biochem. Genet. 2014, 52, 29-37. [CrossRef]

99. Malagrinò, F.; Zuhra, K.; Mascolo, L.; Mastronicola, D.; Vicente, J.B.; Forte, E.; Giuffrè, A. Hydrogen sulfide oxidation: Adaptive changes in mitochondria of SW480 colorectal cancer cells upon exposure to hypoxia. Oxidative Med. Cell. Longev. 2019. [CrossRef]

100. Zhou, Y.; Li, X.-H.; Zhang, C.-C.; Wang, M.-J.; Xue, W.-L.; Wu, D.-D.; Ma, F.-F.; Li, W.-W.; Tao, B.-B.; Zhu, Y.-C. Hydrogen sulfide promotes angiogenesis by downregulating miR-640 via the VEGFR2/mTOR pathway. Am. J. Physiol. Cell Physiol. 2016, 310, C305-C317. [CrossRef]

101. Wang, M.; Yan, J.; Cao, X.; Hua, P.; Li, Z. Hydrogen sulfide modulates epithelial-mesenchymal transition and angiogenesis in non-small cell lung cancer via HIF-1alpha activation. Biochem. Pharmacol. 2020, 172, 113775. [CrossRef] [PubMed]

102. Szabó, C.; Papapetropoulos, A. Hydrogen sulphide and angiogenesis: Mechanisms and applications. Br. J. Pharmacol. 2011, 164, 853-865. [CrossRef] [PubMed]

103. Wong, R.S. Apoptosis in cancer: From pathogenesis to treatment. J. Exp. Clin. Cancer Res. 2011, 30, 87. [CrossRef] [PubMed]

104. Hanahan, D.; Weinberg, R.A. Hallmarks of cancer: The next generation. Cell 2011, 144, 646-674. [CrossRef]

105. Kar, S.; Kambis, T.N.; Mishra, P.K. Hydrogen sulfide-mediated regulation of cell death signaling ameliorates adverse cardiac remodeling and diabetic cardiomyopathy. Am. J. Physiol. Heart Circ. Physiol. 2019, 316, H1237-H1252. [CrossRef]

106. Jha, S.; Calvert, J.W.; Duranski, M.R.; Ramachandran, A.; Lefer, D.J. Hydrogen sulfide attenuates hepatic ischemia-reperfusion injury: Role of antioxidant and antiapoptotic signaling. Am. J. Physiol. Heart Circ. Physiol. 2008, 295, H801-H806. [CrossRef] [PubMed]

107. Rose, P.; Moore, P.K.; Ming, S.H.; Nam, O.C.; Armstrong, J.S.; Whiteman, M. Hydrogen sulfide protects colon cancer cells from chemopreventative agent beta-phenylethyl isothiocyanate induced apoptosis. World J. Gastroenterol. 2005, 11, 3990-3997. [CrossRef]

108. Zheng, D.; Chen, Z.; Chen, J.; Zhuang, X.; Feng, J.; Li, J. Exogenous hydrogen sulfide exerts proliferation, anti-apoptosis, migration effects and accelerates cell cycle progression in multiple myeloma cells via activating the Akt pathway. Oncol. Rep. 2016, 36, 1909-1916. [CrossRef]

109. Zhen, Y.; Pan, W.; Hu, F.; Wu, H.; Feng, J.; Zhang, Y.; Chen, J. Exogenous hydrogen sulfide exerts proliferation/antiapoptosis/angiogenesis/migration effects via amplifying the activation of NF-kappaB pathway in PLC/PRF/5 hepatoma cells. Int. J. Oncol. 2015, 46, 2194-2204. [CrossRef]

110. Tiong, C.X.; Lu, M.; Bian, J.S. Protective effect of hydrogen sulphide against 6-OHDA-induced cell injury in SH-SY5Y cells involves PKC/PI3K/Akt pathway. Br. J. Pharmacol. 2010, 161, 467-480. [CrossRef]

111. Hoesel, B.; Schmid, J.A. The complexity of NF-kappaB signaling in inflammation and cancer. Mol. Cancer 2013, 12, 86. [CrossRef]

112. Rojo de la Vega, M.; Chapman, E.; Zhang, D.D. NRF2 and the Hallmarks of Cancer. Cancer Cell 2018, 34, 21-43. [CrossRef]

113. Lu, Z.; Xu, S. ERK1/2 MAP kinases in cell survival and apoptosis. IUBMB Life 2006, 58, 621-631. [CrossRef] [PubMed]

114. Ray Chaudhuri, A.; Nussenzweig, A. The multifaceted roles of PARP1 in DNA repair and chromatin remodelling. Nat. Rev. Mol. Cell Biol. 2017, 18, 610-621. [CrossRef]

115. Brown, J.S.; O'Carrigan, B.; Jackson, S.P.; Yap, T.A. Targeting DNA Repair in Cancer: Beyond PARP Inhibitors. Cancer Discov. 2017, 7, 20-37. [CrossRef] 
116. Szczesny, B.; Marcatti, M.; Zatarain, J.R.; Druzhyna, N.; Wiktorowicz, J.E.; Nagy, P.; Hellmich, M.R.; Szabo, C. Inhibition of hydrogen sulfide biosynthesis sensitizes lung adenocarcinoma to chemotherapeutic drugs by inhibiting mitochondrial DNA repair and suppressing cellular bioenergetics. Sci. Rep. 2016, 6, 36125. [CrossRef]

117. Li, M.; Liu, Y.; Deng, Y.; Pan, L.; Fu, H.; Han, X.; Li, Y.; Shi, H.; Wang, T. Therapeutic potential of endogenous hydrogen sulfide inhibition in breast cancer (Review). Oncol. Rep. 2021, 45. [CrossRef] [PubMed]

118. Szabo, C. Hydrogen Sulfide, an Endogenous Stimulator of Mitochondrial Function in Cancer Cells. Cells 2021, 10, 220. [CrossRef] [PubMed]

119. Paul, B.D.; Snyder, S.H.; Kashfi, K. Effects of hydrogen sulfide on mitochondrial function and cellular bioenergetics. Redox Biol. 2021, 38, 101772. [CrossRef]

120. Modis, K.; Ju, Y.; Ahmad, A.; Untereiner, A.A.; Altaany, Z.; Wu, L.; Szabo, C.; Wang, R. S-Sulfhydration of ATP synthase by hydrogen sulfide stimulates mitochondrial bioenergetics. Pharmacol. Res. 2016, 113 Pt A, 116-124. [CrossRef]

121. Pavlova, N.N.; Thompson, C.B. The Emerging Hallmarks of Cancer Metabolism. Cell Metab. 2016, 23, 27-47. [CrossRef] [PubMed]

122. Warburg, O.; Wind, F.; Negelein, E. The Metabolism of Tumors in the Body. J. Gen. Physiol. 1927, 8, 519-530. [CrossRef] [PubMed]

123. Miao, P.; Sheng, S.; Sun, X.; Liu, J.; Huang, G. Lactate dehydrogenase A in cancer: A promising target for diagnosis and therapy. IUBMB Life 2013, 65, 904-910. [CrossRef]

124. Untereiner, A.A.; Olah, G.; Modis, K.; Hellmich, M.R.; Szabo, C. $\mathrm{H}_{2}$ S-induced S-sulfhydration of lactate dehydrogenase a (LDHA) stimulates cellular bioenergetics in HCT116 colon cancer cells. Biochem. Pharmacol. 2017, 136, 86-98. [CrossRef]

125. Mittal, V. Epithelial Mesenchymal Transition in Tumor Metastasis. Annu. Rev. Pathol. 2018, 13, 395-412. [CrossRef] [PubMed]

126. Phillips, C.M.; Zatarain, J.R.; Nicholls, M.E.; Porter, C.; Widen, S.G.; Thanki, K.; Johnson, P.; Jawad, M.U.; Moyer, M.P.; Randall, J.W.; et al. Upregulation of Cystathionine-beta-Synthase in Colonic Epithelia Reprograms Metabolism and Promotes Carcinogenesis. Cancer Res. 2017, 77, 5741-5754. [CrossRef]

127. Folkman, J. Angiogenesis: An organizing principle for drug discovery? Nat. Rev. Drug Discov. 2007, 6, 273-286. [CrossRef]

128. Carmi, Y.; Dotan, S.; Rider, P.; Kaplanov, I.; White, M.R.; Baron, R.; Abutbul, S.; Huszar, M.; Dinarello, C.A.; Apte, R.N.; et al. The role of IL-1beta in the early tumor cell-induced angiogenic response. J. Immunol. 2013, 190, 3500-3509. [CrossRef]

129. Ngowi, E.E.; Attia Afzal, M.S.; Khattak, S.; Zaman, S.U.; Khan, N.H.; Li, T.; Jiang, Q.-Y.; Zhang, X.; Duan, S.-F.; Ji, X.-Y. Role of hydrogen sulfide donors in cancer development and progression. Int. J. Biol. Sci. 2021, 17, 73. [CrossRef] [PubMed]

130. Lee, Z.W.; Teo, X.Y.; Tay, E.Y.W.; Tan, C.H.; Hagen, T.; Moore, P.K.; Deng, L.W. Utilizing hydrogen sulfide as a novel anti-cancer agent by targeting cancer glycolysis and $\mathrm{pH}$ imbalance. Br. J. Pharmacol. 2014, 171, 4322-4336. [CrossRef]

131. Lee, Z.W.; Zhou, J.; Chen, C.-S.; Zhao, Y.; Tan, C.-H.; Li, L.; Moore, P.K.; Deng, L.-W. The slow-releasing hydrogen sulfide donor, GYY4137, exhibits novel anti-cancer effects in vitro and in vivo. PLoS ONE 2011, 6, e21077. [CrossRef]

132. Murata, T.; Sato, T.; Kamoda, T.; Moriyama, H.; Kumazawa, Y.; Hanada, N. Differential susceptibility to hydrogen sulfide-induced apoptosis between PHLDA1-overexpressing oral cancer cell lines and oral keratinocytes: Role of PHLDA1 as an apoptosis suppressor. Exp. Cell Res. 2014, 320, 247-257. [CrossRef]

133. Lu, S.; Gao, Y.; Huang, X.; Wang, X. GYY4137, a hydrogen sulfide $\left(\mathrm{H}_{2} \mathrm{~S}\right)$ donor, shows potent anti-hepatocellular carcinoma activity through blocking the STAT3 pathway. Int. J. Oncol. 2014, 44, 1259-1267. [CrossRef]

134. Panza, E.; De Cicco, P.; Armogida, C.; Scognamiglio, G.; Gigantino, V.; Botti, G.; Germano, D.; Napolitano, M.; Papapetropoulos, A.; Bucci, M.; et al. Role of the cystathionine $\gamma$ lyase/hydrogen sulfide pathway in human melanoma progression. Pigment. Cell Melanoma Res. 2015, 28, 61-72. [CrossRef]

135. Sakuma, S.; Minamino, S.; Takase, M.; Ishiyama, Y.; Hosokura, H.; Kohda, T.; Ikeda, Y.; Fujimoto, Y. Hydrogen sulfide donor GYY4137 suppresses proliferation of human colorectal cancer Caco-2 cells by inducing both cell cycle arrest and cell death. Heliyon 2019, 5, e02244. [CrossRef]

136. Cai, F.; Xu, H.; Cao, N.; Zhang, X.; Liu, J.; Lu, Y.; Chen, J.; Yang, Y.; Cheng, J.; Hua, Z.-C. ADT-OH, a hydrogen sulfide-releasing donor, induces apoptosis and inhibits the development of melanoma in vivo by upregulating FADD. Cell Death Dis. 2020, 11, 1-15. [CrossRef] [PubMed]

137. Kaium, M.; Liu, Y.; Zhu, Q.; Liu, C.-h.; Duan, J.-L.; Tan, B.K.; Zhu, Y.Z. $\mathrm{H}_{2} \mathrm{~S}$ donor, S-propargyl-cysteine, increases CSE in SGC-7901 and cancer-induced mice: Evidence for a novel anti-cancer effect of endogenous $\mathrm{H}_{2} \mathrm{~S}$ ? PLoS ONE 2011, 6, e20525.

138. Wu, Y.C.; Wang, X.J.; Yu, L.; Chan, F.K.; Cheng, A.S.; Yu, J.; Sung, J.J.; Wu, W.K.; Cho, C.H. Hydrogen sulfide lowers proliferation and induces protective autophagy in colon epithelial cells. PLOS ONE 2012, 7, e37572. [CrossRef]

139. Hellmich, M.R.; Coletta, C.; Chao, C.; Szabo, C. The therapeutic potential of cystathionine $\beta$-synthetase/hydrogen sulfide inhibition in cancer. Antioxid. Redox Signal. 2015, 22, 424-448. [CrossRef] [PubMed]

140. Zhao, Y.; Biggs, T.D.; Xian, M. Hydrogen sulfide $\left(\mathrm{H}_{2} \mathrm{~S}\right)$ releasing agents: Chemistry and biological applications. Chem. Commun. 2014, 50, 11788-11805. [CrossRef]

141. Zheng, Y.; Ji, X.; Ji, K.; Wang, B. Hydrogen sulfide prodrugs-A review. Acta Pharm. Sin. B 2015, 5, 367-377. [CrossRef] [PubMed]

142. Wu, D.; Hu, Q.; Zhu, Y. Therapeutic application of hydrogen sulfide donors: The potential and challenges. Front. Med. 2016, 10, 18-27. [CrossRef]

143. Levinn, C.M.; Cerda, M.M.; Pluth, M.D. Activatable small-molecule hydrogen sulfide donors. Antioxid. Redox Signal. 2020, 32, 96-109. [CrossRef]

144. Yang, C.-T.; Chen, L.; Xu, S.; Day, J.J.; Li, X.; Xian, M. Recent development of hydrogen sulfide releasing/stimulating reagents and their potential applications in cancer and glycometabolic disorders. Front. Pharmacol. 2017, 8, 664. [CrossRef] 
145. Xu, S.; Pan, J.; Cheng, X.; Zheng, J.; Wang, X.; Guan, H.; Yu, H.; Bao, J.; Zhang, L. Diallyl trisulfide, a $\mathrm{H}_{2} \mathrm{~S}$ donor, inhibits cell growth of human papillary thyroid carcinoma KTC-1 cells through a positive feedback loop between $\mathrm{H}_{2} \mathrm{~S}$ and cystathionine-gamma-lyase. Phytother. Res. 2020, 34, 1154-1165. [CrossRef] [PubMed]

146. Ye, M.; Yu, M.; Yang, D.; Li, J.; Wang, H.; Chen, F.; Yu, H.; Shen, T.; Zhu, Q.; Zhou, C. Exogenous hydrogen sulfide donor NaHS alleviates nickel-induced epithelial-mesenchymal transition and the migration of A549 cells by regulating TGF- $\beta 1 / \mathrm{Smad} 2 / \mathrm{Smad} 3$ signaling. Ecotoxicol. Environ. Saf. 2020, 195, 110464. [CrossRef] [PubMed]

147. Li, H.; Xu, F.; Gao, G.; Gao, X.; Wu, B.; Zheng, C.; Wang, P.; Li, Z.; Hua, H.; Li, D. Hydrogen sulfide and its donors: Novel antitumor and antimetastatic therapies for triple-negative breast cancer. Redox Biol. 2020, 34, 101564. [CrossRef] [PubMed]

148. Marcotte, P.; Walsh, C. Active site-directed inactivation of cystathionine $\gamma$-synthetase and glutamic pyruvic transaminase by propargylglycine. Biochem. Biophys. Res. Commun. 1975, 62, 677-682. [CrossRef]

149. Asimakopoulou, A.; Panopoulos, P.; Chasapis, C.T.; Coletta, C.; Zhou, Z.; Cirino, G.; Giannis, A.; Szabo, C.; Spyroulias, G.A.; Papapetropoulos, A. Selectivity of commonly used pharmacological inhibitors for cystathionine $\beta$ synthase (CBS) and cystathionine $\gamma$ lyase (CSE). Br. J. Pharmacol. 2013, 169, 922-932. [CrossRef]

150. Bucci, M.; Mirone, V.; Di Lorenzo, A.; Vellecco, V.; Roviezzo, F.; Brancaleone, V.; Ciro, I.; Cirino, G. Hydrogen sulphide is involved in testosterone vascular effect. Eur. Urol. 2009, 56, 378-384. [CrossRef] [PubMed]

151. Bucci, M.; Papapetropoulos, A.; Vellecco, V.; Zhou, Z.; Pyriochou, A.; Roussos, C.; Roviezzo, F.; Brancaleone, V.; Cirino, G. Hydrogen sulfide is an endogenous inhibitor of phosphodiesterase activity. Arter. Thromb. Vasc. Biol. 2010, 30, 1998-2004. [CrossRef]

152. Lee, Z.-W.; Low, Y.-L.; Huang, S.; Wang, T.; Deng, L.-W. The cystathionine $\gamma$-lyase/hydrogen sulfide system maintains cellular glutathione status. Biochemical. J. 2014, 460, 425-435. [CrossRef]

153. Szabó, C. Hydrogen sulphide and its therapeutic potential. Nat. Rev. Drug Discov. 2007, 6, 917-935. [CrossRef]

154. Tanase, S.; Morino, Y. Irreversible inactivation of aspartate aminotransferases during transamination with L-propargylglycine. Biochem. Biophys. Res. Commun. 1976, 68, 1301-1308. [CrossRef]

155. Burnett, G.; Marcotte, P.; Walsh, C. Mechanism-based inactivation of pig heart L-alanine transaminase by L-propargylglycine. Half-site reactivity. J. Biol. Chem. 1980, 255, 3487-3491. [CrossRef]

156. Mitra, J.; Bhattacharyya, D. Irreversible inactivation of snake venom l-amino acid oxidase by covalent modification during catalysis of 1-propargylglycine. FEBS Open Bio 2013, 3, 135-143. [CrossRef]

157. Szabo, C.; Papapetropoulos, A. International union of basic and clinical pharmacology. CII: Pharmacological modulation of $\mathrm{H}_{2} \mathrm{~S}$ levels: $\mathrm{H}_{2} \mathrm{~S}$ donors and $\mathrm{H}_{2} \mathrm{~S}$ biosynthesis inhibitors. Pharmacol. Rev. 2017, 69, 497-564. [CrossRef]

158. Yadav, P.K.; Yamada, K.; Chiku, T.; Koutmos, M.; Banerjee, R. Structure and kinetic analysis of $\mathrm{H}_{2} \mathrm{~S}$ production by human mercaptopyruvate sulfurtransferase. J. Biol. Chem. 2013, 288, 20002-20013. [CrossRef]

159. Yang, J.; Minkler, P.; Grove, D.; Wang, R.; Willard, B.; Dweik, R.; Hine, C. Non-enzymatic hydrogen sulfide production from cysteine in blood is catalyzed by iron and vitamin B6. Commun. Biol. 2019, 2, 194. [CrossRef]

160. Zuhra, K.; Augsburger, F.; Majtan, T.; Szabo, C. Cystathionine-beta-Synthase: Molecular Regulation and Pharmacological Inhibition. Biomolecules 2020, 10, 697. [CrossRef] [PubMed]

161. McCune, C.D.; Chan, S.J.; Beio, M.L.; Shen, W.; Chung, W.J.; Szczesniak, L.M.; Chai, C.; Koh, S.Q.; Wong, P.T.-H.; Berkowitz, D.B. "Zipped synthesis" by cross-metathesis provides a cystathionine $\beta$-synthase inhibitor that attenuates cellular $\mathrm{H}_{2} \mathrm{~S}$ levels and reduces neuronal infarction in a rat ischemic stroke model. ACS Cent. Sci. 2016, 2, 242-252. [CrossRef] [PubMed]

162. Druzhyna, N.; Szczesny, B.; Olah, G.; Módis, K.; Asimakopoulou, A.; Pavlidou, A.; Szoleczky, P.; Gerö, D.; Yanagi, K.; Törö, G. Screening of a composite library of clinically used drugs and well-characterized pharmacological compounds for cystathionine $\beta$-synthase inhibition identifies benserazide as a drug potentially suitable for repurposing for the experimental therapy of colon cancer. Pharmacol. Res. 2016, 113, 18-37.

163. Niu, W.; Wu, P.; Chen, F.; Wang, J.; Shang, X.; Xu, C. Discovery of selective cystathionine $\beta$-synthase inhibitors by high-throughput screening with a fluorescent thiol probe. MedChem Comm 2017, 8, 198-201. [CrossRef]

164. Niu, W.; Chen, F.; Wang, J.; Qian, J.; Yan, S. Antitumor effect of sikokianin C, a selective cystathionine $\beta$-synthase inhibitor, against human colon cancer in vitro and in vivo. MedChem Comm 2018, 9, 113-120. [CrossRef] [PubMed]

165. Brancaleone, V.; Esposito, I.; Gargiulo, A.; Vellecco, V.; Asimakopoulou, A.; Citi, V.; Calderone, V.; Gobbetti, T.; Perretti, M.; Papapetropoulos, A. d-Penicillamine modulates hydrogen sulfide (H2S) pathway through selective inhibition of cystathionine- $\gamma-$ lyase. Br. J. Pharmacol. 2016, 173, 1556-1565. [CrossRef] [PubMed]

166. Corvino, A.; Severino, B.; Fiorino, F.; Frecentese, F.; Magli, E.; Perissutti, E.; Santagada, V.; Bucci, M.; Cirino, G.; Kelly, G. Fragment-based de novo design of a cystathionine $\gamma$-lyase selective inhibitor blocking hydrogen sulfide production. Sci. Rep. 2016, 6, 34398. [CrossRef]

167. Bhattacharjee, A.; Sinha, A.; Ratia, K.; Yin, L.; Delgado-Rivera, L.; Petukhov, P.A.; Thatcher, G.R.; Wardrop, D.J. 2-Arylidene hydrazinecarbodithioates as potent, selective inhibitors of cystathionine $\gamma$-lyase (CSE). ACS Med. Chem. Lett. 2017, 8, 1241-1245. [CrossRef]

168. Hu, Y.; Wang, L.; Han, X.; Zhou, Y.; Zhang, T.; Wang, L.; Hong, T.; Zhang, W.; Guo, X.-X.; Sun, J. Discovery of a Bioactive Inhibitor with a New Scaffold for Cystathionine $\gamma$-Lyase. J. Med. Chem. 2018, 62, 1677-1683. [CrossRef] [PubMed] 
169. Wang, L.; Shi, H.; Zhang, X.; Zhang, X.; Liu, Y.; Kang, W.; Shi, X.; Wang, T. I157172, a novel inhibitor of cystathionine $\gamma$-lyase, inhibits growth and migration of breast cancer cells via SIRT1-mediated deacetylation of STAT3. Oncol. Rep. 2019, 41, 427-436. [CrossRef] [PubMed]

170. Hanaoka, K.; Sasakura, K.; Suwanai, Y.; Toma-Fukai, S.; Shimamoto, K.; Takano, Y.; Shibuya, N.; Terai, T.; Komatsu, T.; Ueno, T. Discovery and mechanistic characterization of selective inhibitors of $\mathrm{H}_{2} \mathrm{~S}$-producing enzyme: 3-mercaptopyruvate sulfurtransferase (3MST) targeting active-site cysteine persulfide. Sci. Rep. 2017, 7, 40227. [CrossRef]

171. Takano, Y.; Echizen, H.; Hanaoka, K. Fluorescent probes and selective inhibitors for biological studies of hydrogen sulfide-and polysulfide-mediated signaling. Antioxidants Redox Signal. 2017, 27, 669-683. [CrossRef]

172. Sasakura, K.; Hanaoka, K.; Shibuya, N.; Mikami, Y.; Kimura, Y.; Komatsu, T.; Ueno, T.; Terai, T.; Kimura, H.; Nagano, T. Development of a highly selective fluorescence probe for hydrogen sulfide. J. Am. Chem. Soc. 2011, 133, 18003-18005. [CrossRef] [PubMed]

173. Bantzi, M.; Augsburger, F.; Loup, J.; Berset, Y.; Vasilakaki, S.; Myrianthopoulos, V.; Mikros, E.; Szabo, C.; Bochet, C.G. Novel Aryl-Substituted Pyrimidones as Inhibitors of 3-Mercaptopyruvate Sulfurtransferase with Antiproliferative Efficacy in Colon Cancer. J. Med. Chem. 2021, 64, 6221-6240. [CrossRef] [PubMed] 